\title{
A DESCRIPTIVE STUDY ON FACTORS AFFECTING THE USE OF LEARNING APPROACH AMONG ACCOUNTING EDUCATION STUDENTS AT UNIVERSITAS NEGERI MEDAN
}

\author{
Iis Sundari ${ }^{1 *}$ Lianti $^{1}$, Hidaya Tul Karima ${ }^{1}$, Yulita Triadiarti ${ }^{2}$, Tapi Rumondang Siregar ${ }^{2}$ \\ ${ }^{1}$ Department of Accounting Education, Faculty of Economics, Universitas Negeri Medan, Medan, Indonesia \\ ${ }^{2}$ Department of Accounting, Faculty of Economics, Universitas Negeri Medan, Medan, Indonesia \\ * Corresponding Author: iissundari09@gmail.com
}

\begin{abstract}
Understanding of learning material, especially accounting material, has an impact on the achievement of students' learning outcomes. The research aims to look at the factors that influence the learning approach of Unimed accounting education students. This research was carried out in the FE UNIMED using questionnaires distributed to students of the Accounting Education Program batch of 2015 and 2016, amounting 60 and 68 students from each batch. The selection of batches is based on the type of curriculum applied to each batch, namely the Indonesian National Qualification Framework (abbreviated as KKNI) for 2016 and the non-KKNI for 2015. The approach used in this study was a qualitative approach, with the analysis used was descriptive statistical analysis on factors such as interest, motivation, learning style, anxiety, institutional, and learning strategies. The descriptive analysis shows that except for the interest indicating that non-KKNI students have a higher interest in applying a variety of learning approaches of Non-KKNI students than their KKNI peers, other factors are similar between students from two batches.
\end{abstract}

Keywords: Interest; Motivation; Learning Style; Anxiety; Institutional.

\section{INTRODUCTION}

The goals of the learning process are a change in behavior in both aspects of knowledge (cognitive), attitude (affective), and psychomotor aspects. One of those changes is in the cognitive aspect. Changes in cognitive aspects are obtained from how the understanding of the material during the learning process takes place. Understanding of learning material, especially accounting material, has an impact on the achievement of learning outcomes. A good learning outcome requires an appropriate way to be able to interact with the new information and knowledge obtained, which is mentioned in the learning approach. The learning approach is a way that individuals do in interacting and processing new information obtained in learning activities. By applying a good learning approach, the achievements that will be obtained will also be good.

The learning approach is inseparable from the factors that influence it, among others, interests, anxiety, motivation, learning styles, institutions, and learning strategies. Interest is one of the factors that can affect a person's business. Strong interest will lead to persistent efforts seriously and not easily discouraged in facing challenges in learning. If a student has a desire to learn, he will quickly be able to understand and comprehend and remember it.

Anxiety experienced by each student when the learning process of accounting courses takes place makes its own anxiety especially, whether it is related when presenting material given by lecturers or when not attending lectures for two times in a row. Motivation is a mental drive that drives and directs human behavior, including learning behavior. Motivation is an important factor, which can encourage students to express their ability to do any learning activities so that behavior changes occur to achieve a goal in the form of high learning achievement.

Learning style gives students a tendency to adopt certain strategies in their learning as a form of responsibility to get a learning approach that is suitable for the demands of learning in class and the demands of accounting courses. Institutions or facilities, facilities, and infrastructure will have an impact on the learning process and students' understanding of accounting material so that the facilities and conditions of the institution of an institution will have a positive effect on student understanding.

Every individual has a strategy in understanding accounting material. These strategies are strategies that are used by students to solve certain learning problems. To complete a student's learning task requires involvement in the processes of thinking and behaving, skimming or skimming the main titles, summarizing, and taking notes, while also monitoring the way of thinking themselves. 


\section{LITERATURE REVIEW \\ Learning Approach}

Success in learning is not only determined by intelligence alone. Besides intelligence, another factor that plays an important role is the approach in learning, in general, the learning approach has an important contribution to academic success, and especially in the academic achievement of a student. By applying a good learning approach, the achievements that will be obtained will also be good.

Accordingly, Gilakjani (in Dejene et al., 2018) posits that learning approaches are behaviors in which individuals perceive and process information in learning situations. On the other hand, Abedin et al. (in Dejene et al., 2018) define the learning approach as a way of individuals interact with new information obtained. From these definitions, it can be concluded that the learning approach is a way that individuals do in interacting and processing new information obtained in learning activities.

\section{Interest}

The term of interest refers to "the tendency of a high heart towards something. Interest is a characteristic that is relatively fixed in a person. Interest has a great influence on the activities of someone because as it justifies someone's action. Without an interest, someone can not do anything. Interest is one of the factors that can affect a person's business. Strong interest will lead to persistent efforts seriously and not easily discouraged in facing challenges. If a student has a desire to learn, he will quickly be able to understand and remember it.

\section{Anxiety}

According to Freud (in Alwisol, 2005: 28), anxiety is the function of the ego to warn individuals about the possibility of a danger coming so that a proper response can be prepared. Anxiety functions as a mechanism that protects the ego because anxiety signals to us that there is danger, and if no proper action is taken, then the danger will increase until the ego is defeated.

Anxiety involves psychological and physical components. This is in every different individual form. These symptoms are the result of the stimulation of the autonomic and visceral nervous systems. Individuals will complain of frequent urination or difficulty urinating, heartburn, diarrhea, bloating, stomach pain, cold sweat, palpitations, high blood pressure, headaches, and shortness of breath.

\section{Motivation}

Motivation is a mental drive that drives and directs human behavior, including learning behavior. In motivation, there is a desire to activate, move, channel, and direct individual attitudes and behavior (Koeswara, 1989; Siagian, 1989; Schein, 1991; Biggs \& Telfer, 1987 in Dimyati and Mudjiono (2002).

\section{Learning Style}

According to DePorter \& Hernacki (2013: 110), "learning styles are a combination of how it absorbs, and then organizes and processes information." Meanwhile, according to Fleming and Mills, "learning style is the tendency of students to adopt certain strategies in their learning as a form of responsibility to get a learning approach that is appropriate to the demands of learning in class or school and the demands of the subjects."

\section{Institutional}

Uphoff (1992) and Fowler (1992) state that institutional is "a complex of norm and behavior that persists over time by serving some socially valued purposes" while the organization is a recognized and accepted role structure. Referring to the institutional concept proposed by Gilin and Gilin (1954) about the certain level of stability of the institution, Horton and Hunt (1984) about the routine of the institution, and Uphoff (1986) in Saptana (2006) which states that the institution as a stable pattern of behavior, valued and valid for a long time, then the other main part that is important to consider in the discussion of institutional performance is about patterns of behavior or patterns of interaction that exist between actors in an institution.

\section{Learning Strategy}

Specifically, the learning strategy is explained by Michael Pressley (1991) (in Trianto, 2013: 139), which states that: Learning strategies are cognitive operators including and consisting of processes directly involved in completing a task (learning). These strategies are strategies that students use to solve certain learning problems. To complete a student's learning task requires involvement in the processes of thinking and behaving, skimming or skimming the main titles, summarizing, and making notes, while also monitoring the way of thinking themselves.

\section{RESEARCH METHOD}

The population in this study are Non-KKNI, and KKNI students originated from classes of 2015 and 2016 Accounting Education Undergraduate Program. The total number of students in the 2015 Accounting Accounting education program was 109 people and the number of students in 2016 education, namely 121 people. The sampling technique 
in the study is a random sampling technique using the Slovin formula to generate 60 Non-KKNI students and 68 KKNI students, respectively.

The approach used in this research is a qualitative approach with the analysis used is descriptive statistical analysis. This research was designed in the form of survey research. In this study, researchers used a questionnaire as a technique for collecting data from respondents. This descriptive statistical analysis is used to describe the characteristics of the sample from both batches with regards to observed variables: interest, motivation, learning style, anxiety, institutional, and learning strategies.

\section{RESULT AND DISCUSSION}
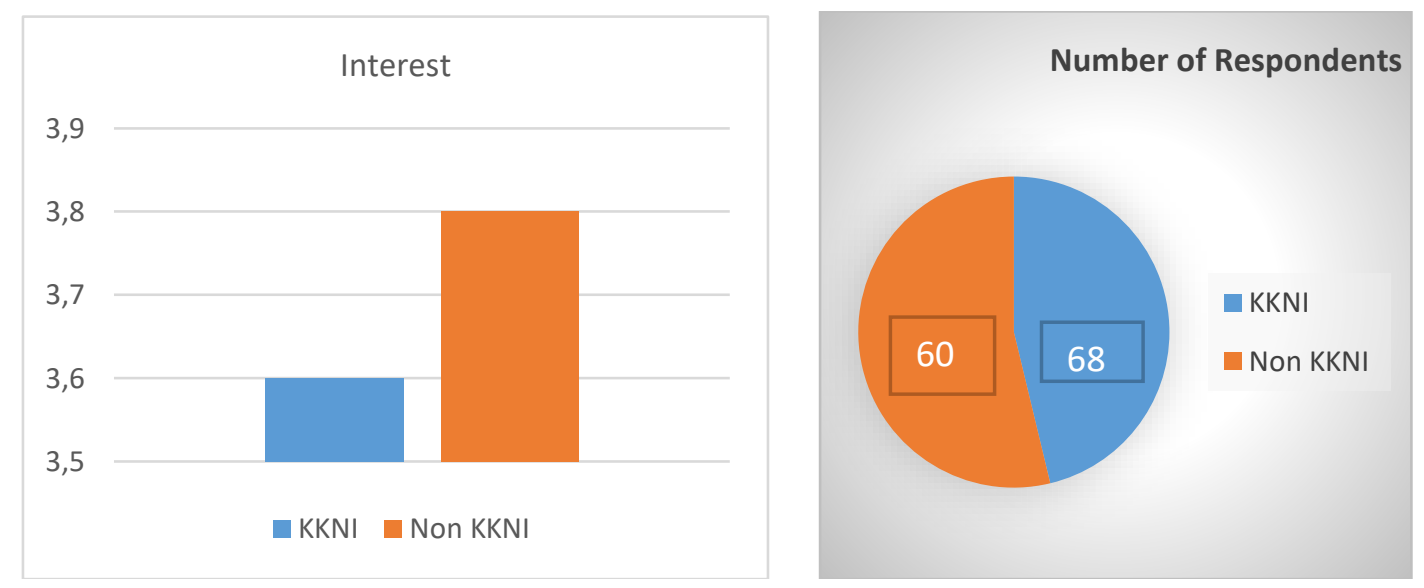

Figure 1. Graphs of Descriptive Statistic on Interest.

The diagram above shows that there are differences in the level of interest between KKNI students and Non-KKNI students. It is seen from the large level of interest in KKNI students who have an average value of 3.6 with a sample of 60 people, and interest in Non-KKNI students has a value of 3.8 with a total sample of 68 people. This shows that the level of interest of Non-KKNI students is greater than KKNI students. Non-KKNI students listen more and note things that are considered important when lecturers deliver accounting subject matter compared to KKNI students. This is because KKNI students are accustomed to self-study with the demands of the work to be done, so they prepare themselves by studying the material to be discussed in class. This preparation results in a lack of interest in taking notes when the lecturer explains the material of accounting courses.
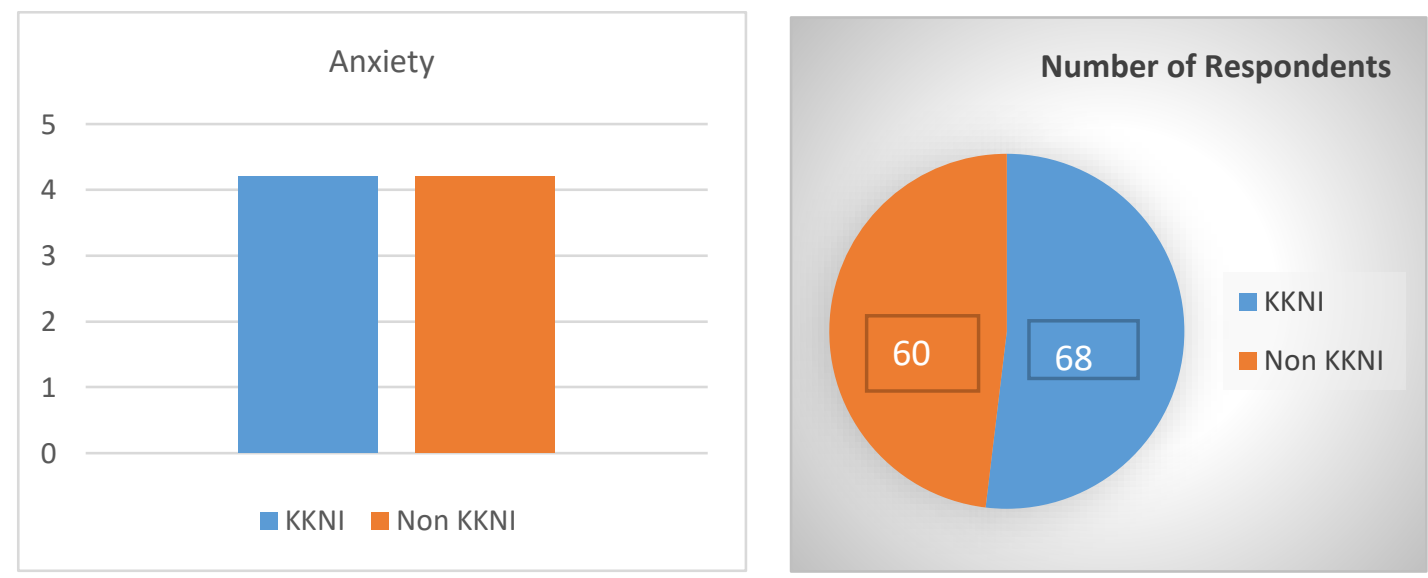

Figure 2. Graphs of Descriptive Statistic on Anxiety.

Anxiety among KKNI and Non-KKNI students have the same average value of 4.2 with different sample sizes, namely 68 KKNI students and 63 Non-KKNI students. It shows that there are similarities in anxiety between KKNI and NonKKNI students. It was seen from the anxiety when not taking accounting courses two times in a row. This anxiety is caused by concerns about having bad grades, violating contracts that have been agreed between students and lecturers, as well as being afraid of missing accounting material related to each other. 


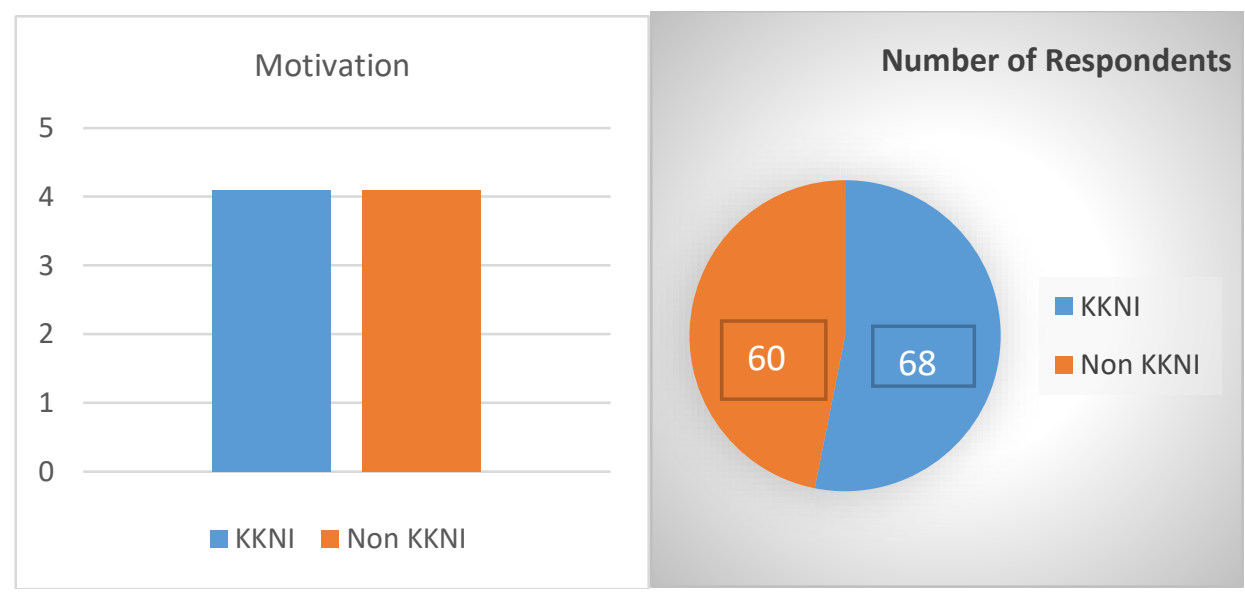

Figure 3. Graphs of Descriptive Statistic on Motivation.

Motivation among KKNI students and Non-KKNI students has the same average value of 4.1 with different sample sizes, namely 68 KKNI students and 60 Non-KKNI students. It can be seen from a similar motivation between KKNI students and Non-KKNI students. Motivation is divided into two, namely intrinsic motivation and extrinsic motivation. Intrinsic motivation arises from within oneself without any coercion or encouragement from others, but on the basis of one's own volition, whereas extrinsic motivation is a working driver that comes from outside the individual so that someone wants to take action (Putra and Frianto, 2013). Based on the data obtained, KKNI and Non-KKNI students, on average, choose to "agree" to one of the statement items about learning in earnest when remembering messages from parents that are extrinsic motivation. In addition, there is intrinsic motivation that does not dominate the choice of "agree" respondents about learning seriously to obtain satisfactory results, study seriously when accounting subject matter is interesting, and always do what is given by the lecturer and try to do it yourself without the help of others.

In particular, KKNI students have been assigned six specific tasks, including Routine Tasks, Critical Journal Review, Critical Book Review, Mini Research, Engineering Ideas, and Projects. These tasks are the reasons for their desire to get high grades so that their motivation is high. Vice versa, in Non-KKNI students without six assignments still have high motivation and desire to obtain satisfactory grades, which is a factor driving high motivation.
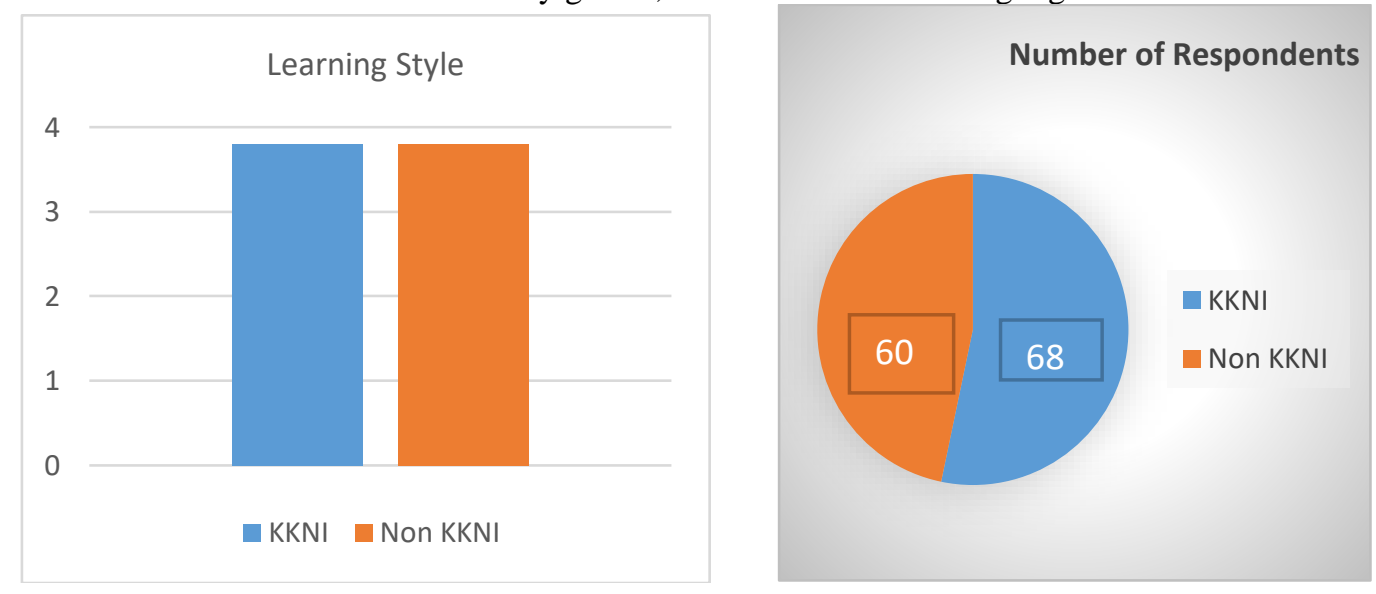

Figure 4. Graphs of Descriptive Statistic on Learning Style.

Learning styles among KKNI and Non-KKNI students have the same average value of 3.8 with a different number of samples, namely 57 KKNI students and 50 Non-KKNI students. It shows that there are similarities in learning styles between KKNI and Non-KKNI students. It can be seen from the learning style of students who like to make small notes when learning takes place, supported with a proper learning material enabling students to answer questions given by the lecturer easier. 

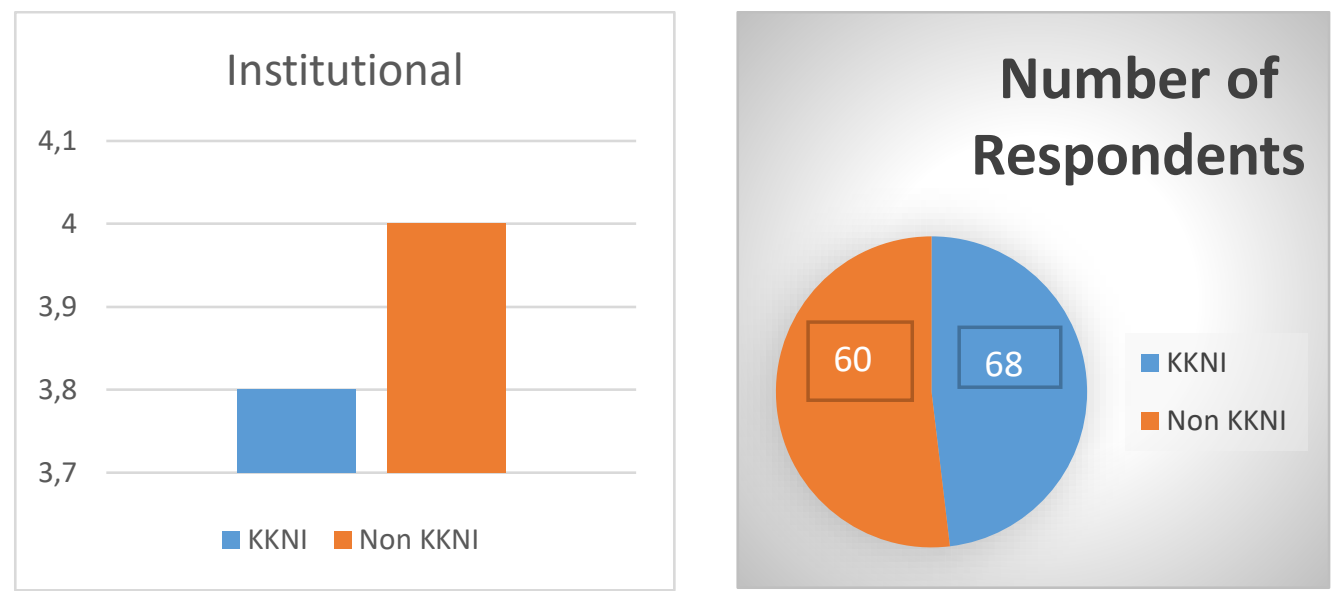

Figure 5. Graphs of Descriptive Statistic on Institutional.

The diagram above shows that there are institutional differences between the KKNI and the Non-KKNI. It can be seen from the average size of institutional KKNI students by 3.8 and Non-KKNI students, as shown in the pie diagram. This shows that the average Non-KKNI student is greater than the KKNI student. Non-KKNI students make more use of the facilities and infrastructure available in the lecture environment, such as a learning park that can be used as a place for joint discussions to discuss material on accounting courses. This is because the tasks given are sometimes not provided in the existing learning material. Thus, Non-KKNI students use different campus facilities to discuss and explore more learning material. As for KKNI students, the atmosphere and condition of comfortable and clean classrooms have a good impact on understanding the accounting material. In contrary to their counterparts, the KKNI students develop a better understanding of subjects they are dealing with by completing all six assignments and work solely using in-campus facilities.
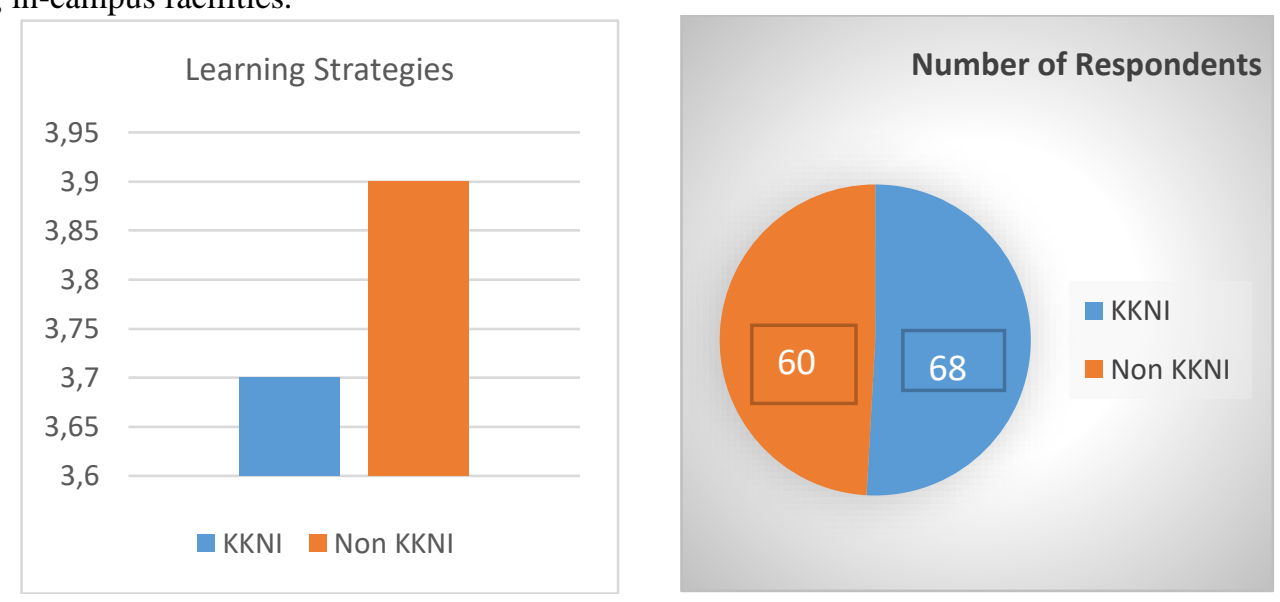

Figure 6. Graphs of Descriptive Statistic on Learning Strategies.

The diagram above shows that there is an average difference in the strategy between KKNI and Non-KKNI. It can be seen from the average size of the strategy of KKNI students by 3.7 and Non-KKNI students by 3.9, respectively. This shows that the average strategy of Non-KKNI students is greater than KKNI students. Non-KKNI students read more articles or accounting textbooks and try to understand their contents compared to KKNI students. This is because the tasks assigned to KKNI students are more than for Non-KKNI students so that the desire to read accounting articles or textbooks, as well as the attempt to understand them, is reduced.

Tabel 1. Percentage of 6 Indicators.

\begin{tabular}{|c|c|c|}
\hline Indicator & KKNI & Non KKNI \\
\hline Interest & $15,44 \%$ & $15,95 \%$ \\
\hline Anxiety & $18,04 \%$ & $17,56 \%$ \\
\hline Motivation & $17,57 \%$ & $17,26 \%$ \\
\hline Learning Styles & $16,41 \%$ & $16,06 \%$ \\
\hline Institusional & $16,54 \%$ & $16,84 \%$ \\
\hline Strategy & $15,97 \%$ & $16,31 \%$ \\
\hline
\end{tabular}


Based on the diagram above, with the descriptive analysis that the factors that influence learning approaches between KKNI and Non-KKNI students have similarities in interests, anxiety, motivation, institutions, learning styles, and strategies. However, there are differences in the percentage of each indicator.

Table 2. Learning Orientation.

\begin{tabular}{|l|l|l|}
\hline \multicolumn{1}{|c|}{ Learning Orientation } & \multicolumn{2}{|c|}{ Indicator } \\
\cline { 2 - 3 } & \multicolumn{1}{|c|}{ KKNI } & \multicolumn{1}{c|}{ Non KKNI } \\
\hline Meaning & Learning Styles & Learning Styles \\
\hline Reproducing & $\begin{array}{l}\text { Interest, Motivation, } \\
\text { Institusional, Strategy }\end{array}$ & $\begin{array}{l}\text { Readability, Motivation, Institusional, } \\
\text { Strategy }\end{array}$ \\
\hline Achieving & \multicolumn{1}{|c|}{-} \\
\hline Non-academic & Anxiety & Anxiety \\
\hline
\end{tabular}

The table above shows that there are links between the six indicators and learning orientation, from the data obtained, for indicators of interest, motivation, learning styles, institutions, and strategies, including Reproducing. In the Meaning orientation with regards to the characteristics of deep learning, the seriousness of learning effort, able to connect between ideas, the use of evidence, and intrinsic motivation. Learning style is included in the Meaning because between KKNI, and Non-KKNI students' study hard. It is visible from KKNI students who prefer to make small notes when studying accounting courses, so it is easy to understand the material. However, Non-KKNI students prefer to study with peers, so they are able to understand accounting subject matter.

Reproducing orientation has characteristics such as surface learning, fear of failure, and extrinsic motivation. Interest is included in Reproducing because of the desire of someone who is dominated by the demands of success in participating in learning. Motivation includes Reproducing because the average respondent (KKNI and Non-KKNI students) has extrinsic motivation; there is encouragement from parents. Institutions, including Reproducing, because the facilities and infrastructure provided by the University can have a positive impact on the learning process. The strategy includes Reproducing because seen from the average respondents (KKNI and Non-KKNI students) who are less than 4.0.

Non-academic orientation has characteristics such as irregular learning methods, negative learning attitudes, and low intrinsic motivation. Anxiety is included in Non-Academic because respondents have a high sense of worry if they do not understand the accounting subject matter to be tested, and worry when unable to present accounting material accounting papers in front of the class.

\section{CONCLUSION}

Based on the results of the study above, it can be concluded that the level of interest of Non-KKNI students is greater than KKNI students. It can be seen from the large level of interest from KKNI, which has a value of 3.6 and an interest in Non-KKNI, which has a value of 3.8. There is a similarity of anxiety that has an average value of 4.2. The motivation between KKNI and Non-KKNI students has the same average value of 4.1. Learning styles between KKNI and NonKKNI students have the same average value of 3.8. There are average differences in institutions between KKNI and Non-KKNI. It can be seen from the magnitude of the institutional average of KKNI students by 3.8 and Non-KKNI students by 4 . There is an average difference in strategy between KKNI and Non-KKNI. It can be seen from the average size of the strategy of KKNI students by 3.7 and Non-KKNI students by 3.9. Of the six indicators, there is no significant percentage difference. Learning orientation consists of Meaning, Reproducing, Achieving, and NonAcademic. Learning style indicators between KKNI and Non-KKNI students are included in Meaning. Indicators of interest, motivation, institutional, and strategy are included in the Reproducing orientation of KKNI and Non-KKNI students, while anxiety indicators are included in Non-Academic orientation between KKNI and Non-KKNI students.

\section{REFERENCES}

Dejene, W., Dkk. 2018. Preservice teachers' approaches to learning and their teaching approach preferences: Secondary teacher education program in focus. Cogent Education, 5, 1-15. ISSN:2331-186X.

Arikunto, S. 2013. Prosedur Penelitian: Suatu Pendekatan Praktek. Jakarta: Rineka Cipta.

Biggs, J. B. 1987. Student Approaches To Learning And Studying. Hawthorn, Victoria: Austrian Council of Educational Research.

Putra, Aditia Kamajaya dan Prianto Agus (2013). Pengaruhi Motivasi Intriksik dan Ekstrinsik terhadap kepuasan kerja. Jurnal ilmu Manajemen. Vol.1 No.1

Biggs, J. B. 1987. Student Approaches To Learning And Studying. Hawthorn, Victoria: Austrian Council of Educational Research.

Entwistle, N., Dkk. 2000. Patterns of response to an approaches to studying inventory across contrasting groups and contexts. European Journal of Psychology of Education, 15 (1), 33-48. ISSN: 0256-2928. 
Everaert, E., Dkk. 2017. The relationship between motivation, learning approaches, academic performance and time spent. Accounting Education, 26 (1), 78-107. ISSN: 0963-9284.

Gurning, B., \& Lubis, E. A. 2018. Metodologi Penelitian Pendidikan. Yogyakarta: K-Media.

Alwisol.2005. Psikologi kepribadian. Malang: UMM Press

Sugiyono. 2017. Statistika Untuk Penelitian. Bandung: Alfabeta.

Sugiyono. 2016. Metode Penelitian Kuantitatif Kualitatif dan R\&D. Bandung: Alfabeta.

Biggs, J., Kember, D., \& Leung, D. Y. (2001). The revised two-factor study process questionnaire: $R S P Q-2 F$. British Journal of Educational Psychology, 71(1), 133-149. ISSN: 2044-8279.

Flaming, Mills. 2015. VARK a Guide To Learning Style. Website : $\underline{\text { htp://vark-learn.com }}$ 